\title{
Change of the Microorganisms Quantity in Irrigative Gleyey-Yellow under Vegetable Soils
}

\author{
N. í. Orudzheva \\ Institute of Soil Science and Agrochemistry, Baku, Azerbaijan. \\ Email: naila.56@mail.ru \\ Received September $16^{\text {th }}, 2012$; revised October $25^{\text {th }}, 2012$; accepted November $20^{\text {th }}, 2012$
}

\begin{abstract}
The results of the long-term investigations in dynamics for study of the conditions of taxonomic groups of microorganisms of irrigated gleyey-yellow soils of the subtropical zone under vegetable crops in rotation with the continuous growing of these cultures have been presented. The results of the researches study demonstrated an important vibration of the microorganisms quantity under growing cultures happens. The most quantity of microorganisms, consuming organic nitrogen is observed in irrigative gleyey-yellow soils of the humid subtropical zone. Intensity of mineralization of organic matters was lower in irrigative gleyey-yellow soils. A quantity of microorganisms was lower, but a coefficient of mineralization was higher under continuous cultures as compared the analogous soils under crop rotation. These data show that a type of the soil influence on the rhizosphere microflora insignificantly, while plant shows a significant effect on its quantity and compositions.
\end{abstract}

Keywords: Gleyey-Yellow Soils; Taxonomic Groups of Microorganisms; Crop Rotation; Monoculture; Vegetable

\section{Introduction}

Soil plays an important role in biosphere life, it defines a necessity of organization and conduction of soil monitoring in the environment protection [1]. The biological equilibrium sustained in the soils of natural ecosystems under the impact of various factors can be strongly disturbed under the impact of anthropogenic loads. The biochemical and microbiological soil properties are of particular importance in this context. In this context, data on the microbiological characteristics of soils are necessary, because they make it possible to evaluate the effect of agricultural practices and crop rotation systems on the bio logical properties of soils. Microorganisms play an important role in soil fertility and plant nutrition. More functionality of microb complex, their sensitiveness to any changes in soil give a chance to use from microbiological characters as criterion in estimation of soil condition [2]. Using of the most sensitive microb-biochemical parameter is offered for discovering of not suitable condition appearing in the soil in time [3]. Bacteria, actinomycetes, microssopic fungus are main representatives of the soil microflora. They participate in the process of mineral decay [4].

Polanski et al. [5] noted that soil enrichment with organic matter in the form of humus and plant residues increases the activity of microorganisms and stimulates various biological processes in the soil. Microorganisms play an important role in soil fertility and plant nutrition; their quantity and quality determine the character, intensity, and direction of the soil microbiological processes $[6,7]$. At the same time, method of bioindication of the antropogen violated soils isn't elaborated to end [7,8].

Some scientists show that the soil cultivating standard regulates biological, especially microbiological process to a considerable extent, changes microflora quantity by quantity and quality in agrocenoz and increases a quantity $[9,10]$. The crop rotation plays an important role in improvement of the plant nourishment regime and purposely changing of microflora in the soils under predecessor plants. A quantity of microorganisms in soil depends on feeding standard, intensity of the substance exchange, biology and development phase of the culture. The soils under Lucerne are characterized by being more of microorganisms quantity, but being less in monoculture [11]. According to the reference, the best condition and nourishment regime form, microflora quantity increases, more underground root remnants enter the soil, prevents from decomposition of soil humus matters for humitity collection and preservation in plant alternation in comparison with monoculture in the crop rotation [12].

This study was aimed at revealing the character of the changes in the populations of the main taxonomic groups of microorganisms (bacteria, spore-forming bacteria, actinomycetes, and microscopic fungi) participating in 
the transformation of organic matter in soils of the subtropical zone of Azerbaijan.

\section{Objects and Methods}

\subsection{Objects}

Irrigated gleyey-yellow soils (in WRB-Irragric Gleyic Luvisols) of the moderately humid subtropical zone are formed under the influence of the seasonally wet climate with excessive moistening in the spring and autumn and with insufficient moistening in the summer. The humus content in the upper horizons is $2.5 \%-5.0 \%$, and the soil reaction is slightly acid $\left(\mathrm{pH}_{\mathrm{H}_{2} \mathrm{O}} \quad 5.5-6.5\right.$; the $\mathrm{pH}_{\mathrm{KCl}}$ is 5.0 5.5).

\subsection{The Field Experiments Scheme}

For irrigated gleyey-yellow soils, a five-field vegetablelegumes (kidney beans) crop rotation was chosen (1: tomatoes $\left(\mathrm{N}_{120} \mathrm{P}_{90} \mathrm{~K}_{90}\right)$; 2: white cabbage + corn for silage $\left(\mathrm{N}_{120} \mathrm{P}_{90} \mathrm{~K}_{90}\right)$, 3: bulb onions $\left(\mathrm{N}_{90} \mathrm{P}_{120} \mathrm{~K}_{120}\right)$, 4: kidney beans $\left(\mathrm{N}_{60} \mathrm{P}_{90} \mathrm{~K}_{60}\right)$, and 5: kidney beans $\left(\mathrm{N}_{60} \mathrm{P}_{90} \mathrm{~K}_{60}\right)$ ). The soils under monocultures of tomatoes, white cabbages, corn for silage, bulb onions, and were also examined.

\subsection{Methods}

The number of different groups of microorganisms $\mathrm{s}$ were determined by the inoculation method. 1 qr dry soil is dissolved in the water for analysis, it is diluted some times by taking $1 \mathrm{ml}$ from suspension $\left(10^{-5}\right.$ and $\left.10^{-6}\right)$. From the same suspension $1 \mathrm{ml}$ was planted in the standard nutritious environment and incubated in $30^{\circ} \mathrm{C}$ thermostat for 3 - 5 days. The standard environment was used for definition of taksonomik group microorganisms: the total number of bacteria utilizing organic nitrogen was determined on meat infusion agar (MIA), the total number of bacteria and actinomycetes utilizing mineral nitrogen was determined on starch and ammonia agar (SAA), and the number of soil microscopic fungi was determined on Czapek's medium. Sporforming bacteria was determined in the heated mixed environment during 20 minutes in $80^{\circ} \mathrm{C}$. The total number of colonies grown on the particular medium was counted, and the population density of the particular physiological group of microorganisms was determined. A total quantity of the colonias grown in the environment was calculated for the unity which forms colonia in one qram of dry soil. The plow $(0-25 \mathrm{~cm})$ and subplow $(25-50 \mathrm{~cm})$ layers were subjected to the analysis. The inoculation was performed in triplicate. The statistical processing of the data was performed by the routine methods to ensure a $95 \%$ significance level.

\section{Results and Discussion}

The activity of microorganisms in soils is related to the formation and mineralization of soil humus and inactivation of substances released from plants and inhibiting substances entering the soils with applied chemicals. Investigations performed under different pedoclimatic conditions indicate that the crops exert different effects on the composition and number of microorganisms $[8,13$, 14]. The analysis of the soil microflora includes the determination of the total number of microorganisms in the soil and the populations of particular physiological groups. It is also important to determine the total biological activity diagnosed by the amount of carbonic acid released from the soil and the soil capacity for accumulation of nitrates and cellulose decomposition [15].

The anthropogenic influence on the soil is especially great in intensive farming systems. In this case, the regimes of the soil nutrients, air, and water are subjected to considerable changes. These changes should be carefully studied in order to maintain and improve the soil fertility. The possible competition between plant roots and microorganisms for nutrients (mainly, mineral nitrogen) is one of the adverse effects in agrocenoses [13].

The rhizosphere of each plant is a dynamic system, and soil microorganisms are known to be an important factor of soil fertility [16]. Microorganisms of rhizosphere play an important role in development of plant thanks to mineralization of the soil organic matter (SOM) and weathering of soil minerals $[17,18]$; oppression of the patogen microorganisms - stimulus of the plant disease [16,19]; synthesis of soluble phosphate [20], synthesis of the biological active matter. Though biomass of microorganisms forms only 1\% - 3\% from SOM, microorganisms of rhizosphere play a key role in transformation of the root secretion [21]. Development of the plant subsoil part depends on intensity of plant root exudents and activity of soil microorganisms [22]. The plant nutrition with mineral substances and the crop productivity depend on microorganisms. In this context, a comprehensive study of the soil fertility with due account for the agrochemical and biological soil characteristics are of special interest.

\subsection{Comparative Analysis of the Microorganisms Quantity in Crop Rotation and Monoculture}

We studied the dynamics of the population density of the microorganisms in the soils under crop rotation systems and under continuous vegetable crops. The results of this study demonstrated that the population densities of the soil microorganisms in the rotation systems are highly variable. A sum of microorganisms in soil and plant root, their functional condition depend on agrotechnics being 
applied to agricultural cultures [23].

In the irrigated gleyey-yellow soils, the number of microorganisms under the tomatoes ranged from 2.4 to 3.7 $\times 10^{6}$, the spore-forming bacteria from 0.2 to $0.3 \times 10^{6}$, the actinomycetes from 4.7 to $7.3 \times 10^{5}$, and the microscopic fungi from 3.1 to $4.1 \times 10^{4} \mathrm{CFU} / \mathrm{g}$ soil in the layer of $0-25 \mathrm{sm}$ in the spring-autumn period. The population density of the microorganisms was minimal in the subsurface horizon (Table 1). It is Mishustin's opinion [4] that the maximum biological activity and the maximum biogeneity are typical of the upper layers of the soil profile.

In the variant with white cabbage + corn for silage, the number of microorganisms ranged from 1.8 to $3.2 \times 10^{6}$, the bacteria from 1.1 to $2.3 \times 10^{6}$, the actinomycetes from 4.1 to $5.7 \times 10^{6}$, the spore-forming bacteria from 0.2 to $0.3 \times 10^{6}$, and the microscopic fungi from 42 to 51 $\times 10^{3} \mathrm{CFU} / \mathrm{g}$ soil in the layer of $0-50 \mathrm{sm}$ during the years of the study. The share of bacteria comprised $69.7 \%$, the spore-forming bacteria $9.8 \%$, the actinomycetes $18.8 \%$, and the microscopic fungi $1.7 \%$ of the total number of microorganisms. The number of microorganisms in the layer of $0-50 \mathrm{sm}$ ranged from 1.6 to $3.0 \times$ $10^{6} \mathrm{CFU} / \mathrm{g}$ soil in the case of the continuous growing of white cabbage, and the number of microorganisms was $14 \%$ lower than in the crop rotation. The number of microorganisms in the layer of $0-25 \mathrm{sm}$ ranged from 2.4 to $3.2 \times 10^{6} \mathrm{CFU} / \mathrm{g}$ soil under the corn for silage.

Table 1. Average biogeneity of irrigated gleyey-yellow soils of moderately humid subtropics.

\begin{tabular}{|c|c|c|c|c|c|c|c|c|c|}
\hline \multirow{3}{*}{ Field No., crop } & \multirow{3}{*}{ Depth, sm } & \multicolumn{8}{|c|}{ Total number of microorganisms } \\
\hline & & \multicolumn{4}{|c|}{ Thousand CFU/g dry soil } & \multicolumn{4}{|c|}{$\%$ of the total number } \\
\hline & & Spring & Summer & Autumn & Average & Bacteria & $\begin{array}{c}\text { Sporeforming } \\
\text { bacteria }\end{array}$ & Actinomycetes & $\begin{array}{l}\text { Microscopic } \\
\text { fungi }\end{array}$ \\
\hline \multicolumn{10}{|c|}{ Five-course vegetable-leguminous crop rotation } \\
\hline I & $0-25$ & 3742 & 2440 & 3084 & 3089 & 69.7 & 9.1 & 20.0 & 1.2 \\
\hline \multirow[t]{2}{*}{ Tomato } & $25-50$ & 2707 & 1886 & 2187 & 2260 & 69.3 & 9.5 & 20.1 & 1.2 \\
\hline & $0-50$ & 3225 & 2136 & 2636 & 2675 & 69.5 & 9.3 & 20.0 & 1.2 \\
\hline II & $0-25$ & 3680 & 2072 & 3637 & 3129 & 69.9 & 9.5 & 18.8 & 1.8 \\
\hline White cabbage + & $25-50$ & 2736 & 1604 & 2583 & 2308 & 69.4 & 10.2 & 18.7 & 1.6 \\
\hline corn for silage & $0-50$ & 3208 & 1838 & 3110 & 2719 & 69.7 & 9.8 & 18.8 & 1.7 \\
\hline III & $0-25$ & 3259 & 2047 & 2818 & 2708 & 70.9 & 10.4 & 17.7 & 1.0 \\
\hline Bulb onion & $25-50$ & 2411 & 1497 & 2128 & 2012 & 68.0 & 11.9 & 19.1 & 1.0 \\
\hline IV & $0-25$ & 4152 & 2830 & 3655 & 3546 & 70.5 & 9.4 & 18.4 & 1.7 \\
\hline \multirow[t]{2}{*}{ Kidney bean } & $25-50$ & 2894 & 1842 & 2741 & 2492 & 68.2 & 10.7 & 19.4 & 1.7 \\
\hline & $0-50$ & 3523 & 2336 & 3198 & 3019 & 69.6 & 9.9 & 18.8 & 1.7 \\
\hline $\mathrm{V}$ & $0-25$ & 4028 & 2773 & 3560 & 3454 & 70.6 & 9.6 & 18.3 & 1.5 \\
\hline \multirow[t]{2}{*}{ Kidney bean } & $25-50$ & 2830 & 1792 & 2652 & 2425 & 68.9 & 10.4 & 19.0 & 1.7 \\
\hline & $0-50$ & 3429 & 2283 & 3106 & 2939 & 69.9 & 9.9 & 18.6 & 1.6 \\
\hline \multicolumn{10}{|l|}{ Monoculture } \\
\hline \multirow[t]{3}{*}{ Tomato } & $0-25$ & 3335 & 2373 & 2818 & 2842 & 66.0 & 11.4 & 21.7 & 1.0 \\
\hline & $25-50$ & 2421 & 1517 & 1967 & 1968 & 69.0 & 11.2 & 18.9 & 0.9 \\
\hline & $0-50$ & 2878 & 1945 & 2393 & 2405 & 67.2 & 11.3 & 20.6 & 1.0 \\
\hline White cabbage & $0-25$ & 3312 & 1775 & 2972 & 2686 & 68.4 & 9.7 & 20.8 & 1.0 \\
\hline \multirow[t]{3}{*}{ Corn for silage } & $0-25$ & 3207 & 2432 & 2899 & 2846 & 67.8 & 11.2 & 20.1 & 0.9 \\
\hline & $25-50$ & 2371 & 1598 & 2074 & 2014 & 67.9 & 11.9 & 19.2 & 0.9 \\
\hline & $0-50$ & 2789 & 2015 & 2486 & 2430 & 67.9 & 11.5 & 19.8 & 0.9 \\
\hline \multirow[t]{3}{*}{ Bulb onion } & $0-25$ & 2672 & 1701 & 2072 & 2148 & 67.0 & 10.8 & 21.1 & 1.0 \\
\hline & $25-50$ & 2102 & 1312 & 1680 & 1698 & 69.3 & 10.8 & 18.9 & 1.0 \\
\hline & $0-50$ & 2387 & 1507 & 1877 & 1924 & 68.0 & 10.8 & 20.2 & 1.0 \\
\hline \multirow[t]{3}{*}{ Kidney bean } & $0-25$ & 3327 & 2496 & 3000 & 2941 & 69.4 & 10.4 & 19.2 & 1.0 \\
\hline & $25-50$ & 2500 & 1575 & 2133 & 2069 & 66.9 & 11.5 & 20.4 & 1.2 \\
\hline & $0-50$ & 2914 & 2035 & 2568 & 2506 & 68.4 & 10.9 & 19.7 & 1.1 \\
\hline
\end{tabular}


The number of microorganisms under the bulb onions in the layer of $0-25 \mathrm{~cm}\left(\mathrm{AI}_{\mathrm{a}}^{\mathrm{I}}\right)$ ranged in the springautumn periods from 2.0 to $3.3 \times 10^{6}$, the spore-forming bacteria from 0.2 to $0.3 \times 10^{6}$, the actinomycetes from 3.6 to $5.6 \times 10^{5}$, and the microscopic fungi from 2.3 to $3.2 \times 10^{4} \mathrm{CFU} / \mathrm{g}$ of dry soil. The number of microorganisms ranged from 1.3 to $2.7 \times 10^{6} \mathrm{CFU} / \mathrm{g}$ soil under the monoculture of bulb onions, and the maximum population density was observed in the spring. The number of microorganisms under the onion in crop rotation was $20.7 \%$ greater in the layer of $0-25 \mathrm{sm}$ and $15.6 \%$ greater in the subplow horizon in comparison with the continuous growing. Intensive agricultural use of soils results in permanent degradation and fertility loss [24].

The number of microorganisms under the kidney beans ranged in the layer of $0-25 \mathrm{~cm}$ from 2.8 to $4.2 \times$ $10^{6}$, the spore-forming bacteria from 0.3 to $0.4 \times 10^{6}$, the actinomycetes from 4.7 to $7.9 \times 10^{5}$, and the microscopic fungi from 38 to $69 \times 10^{3} \mathrm{CFU} / \mathrm{g}$ of dry soil. These values slightly decreased in the subplow horizon and comprised $(1.8-2.9) \times 10^{6} \mathrm{CFU} / \mathrm{g}$ soil. The share of bacteria in the crop rotation was $69.6 \%$, the spore-forming bacteria $9.9 \%$, the actinomycetes $18.8 \%$, and the fungi $1.7 \%$ of the total number of microorganisms. The number of microorganisms in the layer of 0 - $50 \mathrm{sm}$ comprised (1.6 $3.3) \times 10^{6} \mathrm{CFU} / \mathrm{g}$ dry soil in the case of the continuous growing of kidney beans.

\subsection{Change of Microorganisms Quantity by Quality Depending on a Season}

The data on the population densities of the microorganisms in the irrigated gleyey-yellow soils demonstrate that the microorganisms are represented in the spring under the optimal temperature and moisture conditions mostly by ammonifying bacteria. The population density of the bacteria gradually decreased by the end of the summer and increased again by the autumn, but it did not reach the spring maximum. The maximum population densities of the microorganisms were observed under the alfalfa and kidney beans and the minimum ones under the onions.

The shares of bacteria and actinomycetes were maximal and the share of microscopic fungi was minimal in the studied soils. Actinomycetes, similar to the sporeforming bacteria, increase their life activity when organic substances in the soil become less available. This group of microorganisms exceed the group of spore-forming bacteria in their population density; actinomycetes reproduce well under neutral and alkaline reactions of the soil solution [25]. The population density of the actinomycetes is determined not only by the soil conditions (the moisture and temperature) and humus content but also by the biological features of the crops in the crop rotations [25]. Actinomycetes participate directly in formation of soil bioproductivity [26], in formation of the biological active matters in the soil and formation of soil nitrogen balance [27].

Depending on the year's conditions and the cultivated crop, the number of actinomycetes in the crop rotation ranged during the growing period from in the ferraliticgley soils from $2.8 \times 10^{5}$ to $3.3 \times 10^{5} \mathrm{CFU} / \mathrm{g}$. The population density of the actinomycetes in the studied soils gradually increased from the spring to the summer and decreased again in the autumn. The studied soils were characterized by the maximum population densities of the bacteria and actinomycetes and by a low number of microscopic fungi $[11,28,29]$. It is known that the agricultural use and especially the cultivation of soils results in a significant decrease of the microscopic fungi in them $[5,30]$.

Polyanskaya et al. [5] consider that the decrease of the number of microscopic fungi in arable soils is one of most serious disturbances of the composition of the soil biota after soil involving into agriculture. This group of microorganisms, despite its paucity (when determined with the inoculation method), is largely responsible for the soil fertility, participating in the destruction of plant and animal residues and in the formation of a water-stable soil structure [16].

The number of microscopic fungi in the crop rotation averaged during the growing period $(2.8-6.0) \times 10^{4}$ $\mathrm{CFU} / \mathrm{g}$ of dry soil in the gleyey-yellow soils. As for the seasonal dynamics of the population density of the fungi, it was the maximal in the spring, it decreased gradually by the end of the summer, and it increased slightly by the end of the plant growth.

\subsection{Mineralization Intensity of the Organic Substances by Microorganisms}

The increase of the intensity of the anthropogenic impact in the arable soil was accompanied by the increase of the number of aminotrophic organisms, and this resulted in the intensification of the processes of the organic compounds' mineralization [31]. The intensity of the mineralization processes can be judged by the coefficients of the mineralization and immobilization [4]. The mineralization coefficient (SAA/MIA) is calculated according to a correlation of microorganisms quantity using of nitrogen mineral form to ammonificators quantity [32].

The mineralization coefficient ranged in the gleyeyyellow soils under the crops in the crop rotation from $0.25-0.29$ and from $0.28-0.32$ under the monoculture. A conclusion can be reached on the basis of the data on the microflora's composition that the processes of the mineralization of the plant and animal residues are relatively intense in the studied soils. The mineralization 
coefficient was greater under the continuously cultivated crops than under the crop rotation.

These data attest to the low effect of the soil type on the rhizosphere microflora and to the considerable effect of the cultivated crops on the number and composition of the soil microbial community.

A total quantity of microorganisms was more till $24 \%$ than maize and head-onion versions for tomato, whiteheaded-cabbage + silage under vegetable bean in crop rotation. The microorganisms quantity in the permanent cropping was less till $39 \%$ as compared with the crop rotation under plants of the same name. It is obvious that microorganisms quantity is determined by growing plants biology more than soil type.

\section{Conclusions}

The following conclusions can be reached on the basis of the data on the long-term study of the dynamics of the amount and composition of the microorganisms in the gleyey-yellow soils of the subtropical zone under vegetable and forage crops.

The microorganisms in the irrigated gleyey-yellow soils were dominated by bacteria and actinomycetes, and the population densities of the spore-forming bacteria and microscopic fungi were relatively lower.

The irrigated gleyey-yellow soils were characterized by the minimal intensity of the mineralization of the plant.

The number of microorganisms was smaller and the mineralization coefficient greater under the monocultures than under the crop rotations.

\section{Acknowledgements}

Work has been executed in Azerbaijan Research Institute of Vegetable growing and in Institute of Soil Science and Agrochemistry of the National Academy of Sciences of Azerbaijan and there was a scientific subject of these Institutes.

\section{REFERENCES}

[1] G. V. Dobrovolsky and L. A. Grishina, "Soil Protection," Moscow, 1985.

[2] A. A. Larionova, D. V. Sapronov, V. O. Lopez de Gerenyu, L. G. Kuznetsova and V. N. Kudeyarov, "Contribution of Plant Root Respiration to the $\mathrm{CO}_{2}$ Emission from Soil," Eurasian Soil Science, Vol. 39, No. 10, 2006, pp. 1248-1266. doi:10.1134/S1064229306100103

[3] E. I. Andreyuk, G. A. Lutinskaya, E. V. Valogurova, V. E. Korirskaya, N. I. Ivanova and A. D. Ostonenko, "Ierarkhic System of Soil Bioindication Being Polluted by Heavy Metals," Euroasian Soil Science, Vol. 2, 1987, pp. 1491-1496.
[4] E. N. Mishustin, "Microorganisms and Farming Productivity," Nauka, Moscow, 1972.

[5] L. M. Polyanskaya, S. M. Lukin and D. G. Zvyagintsev, "Changes in the Composition of the Microbial Biomass of Soils upon Their Cultivation," Eurasian Soil Science, Vol. 7, 1990, pp. 67-74.

[6] Zh. Voinova-Roikova, V. Rankov and G. Ampova, "Microorganisms and Soil Fertility," Agropromizdat, Moscow, 1986.

[7] P. J. A. Howard, "Problems in the Estimation of Biological Activity in Soil," Oicos, Vol. 23, 1972, pp. 235-240.

[8] P. S. Brookes, "The Use of Microbial Parameters in Monitoring Soil Pollution by Heavy Metals," Biology and Plant Fertility of Soil, Vol. 19, No. 4, 1995, pp. 269-279. doi:10.1007/BF00336094

[9] N. H. Orucova, "Ecologo-Biological Estimation of Soils under Vegetable Cultures as the Indicator Fertility of Soils," Journal of International Environmental Application and Science, Vol. 3, No. 5, 2008, pp. 351-357.

[10] A. Mendeshev, K. D. Kardzanov and N. U. Mamutov, "About Biological Activity of North Kazakhstan Soils under Irrigative Condition," Thes. Lec. VII Repress. Cong. of Allunion Society of Scientists, Tashkent, Vol. 2, 1985, p. 148 .

[11] M. P. Babaev and N. I. Orudzheva, "Assessment of the Biological Activity of Soils in the Subtropical Zone of Azerbaijan," Eurasian Soil Science, Vol. 42, No. 10, 2009, pp. 1163-1169. doi:10.1134/S1064229309100111

[12] A. I. Chunderova, "Biochemical Microflora and Soil Fertility," Agronomic Microbiology, 1976, pp. 47-82.

[13] G. S. Kasumova, "Basics of Microbiology and Virology," Maarif, Baku, 1985.

[14] N. I. Orudzheva, "Eco-Biological Evaluation of Irrigated Soils in the Subtropical Zones of Azerbaijan under Vegetable Crops," Ecology and Biology of Soils: Problems of Diagnostics and Indication, Materials of the Int. Sci. Conf., Rostov-on-Don, 2006, pp. 366-367.

[15] M. A. Belousov, "Methods of Microbiological Studies and of the Determination of Microelements," Tashkent, 1973.

[16] P. Babyeva and G. M. Zenova, "Soil Biology," Izd. Mosk. Gos. Univ., Moscow, 1989.

[17] J. F. Dormaar, "Effect of Active Roots on the Decomposition of Organic Matter," Biology and Fertility of Soils, No. 10, No. 2, 1990, pp. 121-136.

[18] D. L. Jones and P. R. Darrah, "Role of Root Derived Organic Acids in the Mobilization of Nutrients from the Rhizosphere," Plant and Soil, Vol. 166, No. 2, 1994, pp. 247-257. doi:10.1007/BF00008338

[19] J. W. Kloepper, "Plant Growh-Promoting Rhizobacteria as Biological Control Agents,” In: F. B. Metting, Ed., Soil Microbial Ecology, Marcel Dekker, New York, 1992, pp. 255-305.

[20] C. Leyval and J. Berthelin, "Rhizodeposition and Net Release of Soluble Organic Compounds by Pine and Beech Seedlings Inoculated with Rhizobacteria and Ectomycorrhizal Fungi," Biology and Fertility of Soils, Vol. 
15, No. 4, 1993, pp. 259-267. doi:10.1007/BF00337210

[21] T. H. Anderson and K. H. Domsch, "Rations of Microbial Biomass Carbon to Total Organic Carbon in Arable Soils," Soil Biology \& Biochemistry, Vol. 21, No. 4, 1989, pp. 471-479. doi:10.1016/0038-0717(89)90117-X

[22] I. V. Yevdokimov, R. Ruser, F. Buegger, M. Marx and J C. Munch, "Interaction between Rhizosphere Microorganisnz and Plant Roots: ${ }^{13} \mathrm{C}$ Fluxes in the Rhizosphere after Pulse Labeling," Eurasian Soil Science, Vol. 40, No. 7, 2007, pp. 852-861. doi:10.1134/S1064229307070095

[23] R. S. Kutuzova, N. I. Vorobev and Yu. V. Kruglov, "Structure of the Microbial Complex in Wheat Rhizosphere under Herbicide Stress," Eurasian Soil Science, Vol. 39, No. 2, 2006, pp. 220-227. doi:10.1134/S1064229306020104

[24] S. Yu. Selivanovskaya, V. Z. Latypova and L. A. Gubaeva, "Microbiological Processes in Gray Forest Soil Treated with Sewage Sludge Compost," Eurasian Soil Science, Vol. 39, No. 4, 2006, pp. 495-501. doi:10.1134/S1064229306040119

[25] G. G. Dzhanaev, A. T. Farniev and Z. G. Dzhanaev, "Impact of Regular Fertilization on the Agrichemical and Biological Properties of Chestnut Soils and Crop Yields in Rotation," Agrokhimiya, No. 10, 2007, pp. 32-38.
[26] D. S. Orlov, O. N. Biryukova and N. I. Sukhanova, "Organic Matter of Soils in Russian Federation," Nauka, Moscow, 1966.

[27] I. V. Kalakutsky and S. S. Sharaya, "Actinomicets and Plants," Progress of Microbiology, Vol. 25, 1990, pp. 2665.

[28] N. I. Orudzheva, "Impact of Biotic Factors on the Activity of Enzymes and Microflora," Agrarnaya Nauka Azerbaidzhana, No. 4-6, 2006, pp. 21-26.

[29] N. I. Orudzheva, "Microbiological Characteristics of Different Types of Irrigated Soils in the Subtropical Zone of Azerbaijan," Eurasian Soil Science, Vol. 44, No. 11, 2011, pp. 1355-1363. doi:10.1134/S1064229311030094

[30] V. D. Mukha and L. I. Vasil'eva, "Changes in the Biological Activity of a Typical Chernozems under the Impact of Its Different Agricultural Uses," Gorkovskii Sel'skokhoz. Inst., Gorky, 1983, pp. 33-36.

[31] N. V. Pol'yakova and N. V. Red'kina, "Changes in Some Microbiological Parameters of Forest-Steppe Soils upon Their Agricultural Use," Agrokhimiya, No. 8, 2007, pp. 71-75.

[32] T. A. Devyatova and A. P. Shcherbakov, "Biological Activity of Chernozems in the Center of the Russian Plain," Eurasian Soil Science, Vol. 39, No. 4, 2006, pp. 502-508. doi:10.1134/S1064229306040120 